\title{
Characteristics of sponge cake prepared by the addition of sweet pumpkin powder
}

\author{
Gyeong-Sook Lee, Gyeong-Phil Han* \\ Division of Foodservice industry, Uiduk University, Gyeongju 38004, Korea
}

단호박 분말을 첨가한 스펀지 케이크의 품질 특성

\author{
이경숙 · 한경필* \\ 위덕대학교 외식산업학부
}

\begin{abstract}
This study investigated the effects of freeze-dried sweet pumpkin powder on the baking of butter sponge cake. Freeze-dried sweet pumpkin powder $(0,3,6,9,12 \%)$ was supplemented during the baking progress and the results were as follows. In terms of the Farinograph characteristics of the batter, the absorption rate increased slightly as the amount of sweet pumpkin powder added increased, and the development time to reach the peak was slightly longer, increasing from 12\%. The amylogram characteristic showed that the gelatinization starting temperature seemed to increase as the amount of sweet pumpkin powder added was increased and the maximum viscosity was lower. The specific gravity of the sponge cake increased as the amount of the pumpkin powder added was increased. From the crust of the sponge cake, the L-values (brightness, $\mathbf{p}<0.01$ ), a-values (redness, $\mathbf{p}<\mathbf{0 . 0 5}$ ), and $b$-values (yellowness, $\mathbf{p}<\mathbf{0 . 0 5}$ ) were significantly lower as the amount of the pumpkin powder added was increased. Volume $(\mathbf{p}<0.01)$ and symmetry index $(\mathbf{p}<\mathbf{0 . 0 5})$ decreased when the sweet pumpkin powder was added. In terms of textual characteristics, hardness increased as the amount of the sweet pumpkin powder was increased $(p<0.05)$. However, when the sweet pumpkin powder was added at $9 \%$ and, $12 \%$, brittleness decreased $(p<0.01)$.
\end{abstract}

Key words : sweet pumpkin powder, sponge cake, specific gravity, amylogram, textual characteristics

\section{서 론}

현대 생활의 다변화와 경제적인 발달로 인하여 의식의 변화와 함께 식생활의 양상도 다양하게 이루어지고 있다. 최근에는 바쁜 생활로 인하여 제과 제빵 제품이 부식에서 점차 주식으로 비중이 증가되면서 소비가 증대하고 있으 며, 건강을 지향하는 추세에 따라 다양한 종류의 식품을 첨가하여 기능성을 높이고 있다(1). 웰빙화에 따른 건강·기 능성 식품에 대한 관심과 천연소재를 이용한 건강 지향적 식품 개발이 활발하게 수행되고 있으며, 제과 제빵 산업에

*Corresponding author. E-mail : gphan@uu.ac.kr Phone : 82-54-760-1605, Fax : 82-54-760-1325

Received 17 July 2018; Revised 27 July 2018; Accepted 31 July 2018

Copyright (c) The Korean Society of Food Preservation. All rights reserved.
서도 다양한 천연 식물성 식품 소재를 첨가한 제품이 소비 자들에게 호응을 얻고 있다(2).

단호박 (Cucurbita spp.)은 박과에 속하는 1 년 생 덩굴성 초본으로 남아메리카 페루가 원산지인 서양계 호박으로 기호성작물이다(3). 함유량이 높은 $\beta$-carotene은 비타민 A 의 좋은 급원이며, 다양한 약리작용을 가지고 있고(4), 구성 당류는 소화 흡습성이 좋다. 또한, 풍부한 섬유질 등으로 부종의 치료 및 이뇨효과가 있으며, 호흡기 질환이 있는 사람에게 저항력을 길러주는 기능성과 함께 영양적으로 우수한 식품이다(5).

서양종 호박 중에서 감미 호박으로 당호박, 밤호박으로 불리우는 단호박은 고랭지 작물로 $1.5 \mathrm{~kg}$ 내외의 작은 크기 이며 진한 녹색의 과피를 가지고, 진황색을 띤 과육은 두껍 고 치밀하며 재래호박보다 당도가 6-7 ${ }^{\circ} \mathrm{Brix}$ 더 높다(6). 단호박은 주로 일본 수출용으로 재배되었다가 90 년대 후반 부터 국내에서 재배가 급증하여 섬유질이 풍부하면서도 
비타민과 $\mathrm{P}, \mathrm{Ca}, \mathrm{Na}$ 등의 영양소도 다량 함유하여 국내 소비가 다양화 되면서 점차적으로 증가되고 있다(5-9). 특 히, 단호박은 호박에 비하여 고형질 함량이 훨씬 높고 arginine, tyrosine, cystine, aspartic acid 등의 필수아미노산 과 oleic acid, linoleic acid 등 불포화 지방산이 풍부하게 들어 있어 영양학적으로 우수하고, 기능성 식품 소재로도 각광 받고 있다(10).

이러한 이유로 단호박은 건강 기능성 식품으로 조리 및 가공 관련 산업에 선호도가 높아서 많이 이용되고 있고 많은 연구가 이루어지고 있으며, 단호박의 영양 성분 및 항산화 활성 $(5,7,11-13)$, 저장 중의 품질 특성(10,14-19)에 관한 연구 논문이 있다. 가공 식품에도 단호박을 첨가하여 영양과 기호성을 증가시키고 있으며, 국수(20), 된장소스 (21), 요구르트(22), 이유식(23), 식혜(24), 과채 음료(25)에 이용이 되고, 서구화된 식생활의 증가로 서양음식인 스톡 (26), 수프 $(27,28)$ 에 첨가하여 다양한 조리법을 제시하고 있다. 그리고 간편식에도 천연 식품을 첨가하여 기능성을 높인 양갱(29), 젤리(30)가 있으며, 예로부터 떡을 즐겨 먹는 식생활의 영향으로 호박떡(31), 두텁떡(32), 설기떡(33)에 넣어서 새로운 맛과 영양을 섭취하면서 부가가치를 높이고 있다.

또한 식생활의 간편화와 서구화로 인하여 제과제빵 제품 의 소비 증가와 함께, 기능성을 부여한 제품의 선호도가 급증하여 천연 식물성 재료이면서 기능성이 우수한 단호박 을 첨가한 식빵(1,2), 하드롤(34), 쿠키(35,36), 머핀(37), 파 운드 케이크 등(38-40)의 제품 연구가 활발히 이루어지고 있다. 이러한 소비자의 기호에 맞추어 맛과 더불어 영양성 과 기능성이 우수한 단호박 분말을 첨가한 스펀지 케이크를 제조하여 부가가치를 높이고 상품성을 증대하여 제과제빵 산업을 활성화 할 수 있다고 사료된다.

따라서 본 연구에서는 영양성과 기능성을 증가시키고 소비자의 기호성이 높은 식품을 개발하고자 동결건조한 단호박 분말의 첨가비율을 달리하여 스펀지 케이크를 제조 하고 반죽의 farinograph, amylograph, 비중의 물리적 특성 과 색도, 부피, 무게, 비용적 및 굽기 손실율 등의 품질특성 검사를 실시하였다. 이로써 소비자들이 섭취하였을 때 선 호도가 높은 제품을 제조하고, 필요한 영양정보 및 다양한 제품으로 소비를 증대시키고 베이커리 산업 발전에 기여하 는 데 자료를 제공하고자 한다.

\section{재료 및 방법}

\section{실험재료}

본 실험에 사용한 단호박은 청도군 각남면에서 재배된 것으로 7월 말에 수확하여 껍질과 씨를 제거해서 다진 다음 $-70^{\circ} \mathrm{C}$ 에서 deep freezer(Model df 9007, IlSin lad Co., Ltd.,
Seoul, Korea)을 이용하여 동결하였다. 동결된 단호박은 동 결 건조기(Model fda 5518, IlSin lad Co., Ltd.)에서 동결 건조 한 후 분쇄기로 분쇄하여 100 mesh 체망을 통과한 분말을 공시 재료로 사용하였다. 밀가루는 미국산 밀로 제 조한 대한제분(박력분 1등급), 설탕(TS Co., Seoul, Korea), 달걀(Nakwon Egg Farm, Gimcheon, Korea), 소금 (Dongkwang Co., Daegu, Korea), 버터(Seoul Milk, Seoul, Korea)를 사용하였다.

\section{제조방법}

단호박 버터스펀지 케이크의 배합비는 Table 1 과 같고, 케이크 제조는 Nagao 등(41)의 방법을 변형한 공립법으로 설탕의 용해성을 증가시키고, 계란의 기포성을 향상시키며 제품의 부피를 크게 하기 위해 더운 방법(hot mixing method)을 사용하였다(Fig 1). 케이크의 반죽은 수직형 반 죽기(Model NVM-95, Dae Young Co., Seoul, Korea)를 사용 하여 믹서볼에 전란을 넣고 골고루 풀어준 후 설탕과 소금 을 투입하여 중탕 $43^{\circ} \mathrm{C}$ 로 가온하여 중속 30 초, 고속 6 분간 최대 휘핑한다. 그 다음 중속 2 분, 저속 1 분간 믹싱하여 기포형성이 최적 상태로 형성되면, 밀가루와 단호박 분말 비율을 달리한 각각의 혼합물을 체로 쳐서 넣고 골고루

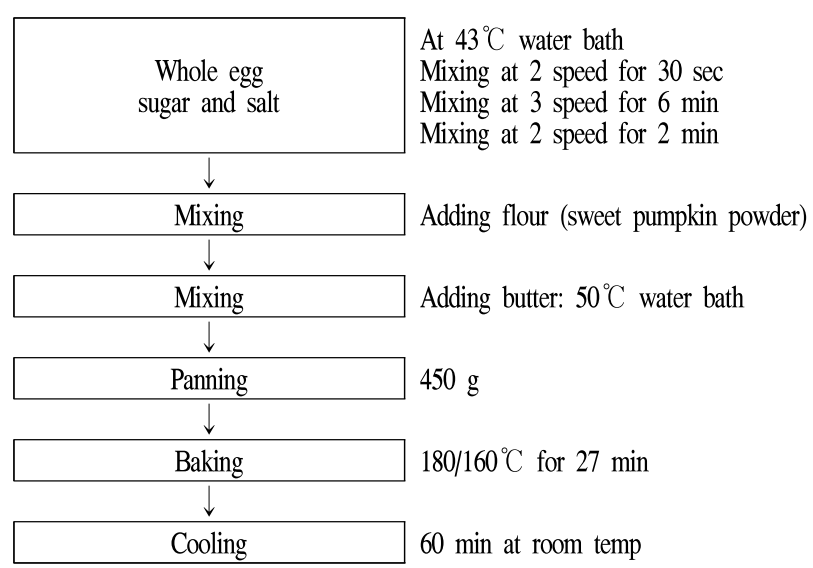

Fig. 1. Process of butter sponge cake preparation.

Table 1. Formulas for butter sponge cakes prepared with different levels of sweet pumpkin powder

\begin{tabular}{lccccc} 
& \multicolumn{3}{r}{ (unit: g) } \\
\hline \multirow{2}{*}{ Ingredients } & \multicolumn{3}{c}{ Addition levels of } & sweet & pumpkin powder (\%) \\
\cline { 2 - 6 } \multicolumn{1}{c}{ Soft flour } & 0 & 3 & 6 & 9 & 12 \\
Sweet pumpkin powder & 0 & 3 & 6 & 9 & 12 \\
Butter & 20 & 20 & 20 & 20 & 20 \\
Egg & 180 & 180 & 180 & 180 & 180 \\
Sugar & 120 & 120 & 120 & 120 & 120 \\
Salt & 1 & 1 & 1 & 1 & 1 \\
\hline
\end{tabular}


혼합한 다음 $50^{\circ} \mathrm{C}$ 로 중탕한 버터를 가볍게 혼합하였다. 이 때의 반죽온도는 $25 \pm 1^{\circ} \mathrm{C}$ 로 하였다.

완료된 이 반죽을 원형팬 3 호(직경 $21 \mathrm{~cm}$, 높이 $4.5 \mathrm{~cm}$ )에 $450 \mathrm{~g}$ 의 반죽을 넣고 윗불 $180^{\circ} \mathrm{C}$ 아랫불 $160^{\circ} \mathrm{C}$ 로 예열된 전기오븐(Model FDO-7102. Dae Young Co., Seoul, Korea) 에서 27 분간 굽기한 다음 실온에서 1 시간 방냉하여 시료로 사용하였다.

\section{일반성분}

시료로 사용된 단호박 분말의 일반 성분은 $\mathrm{AOAC}(42)$ 방법에 따라 실시하였다. 수분은 $105^{\circ} \mathrm{C}$ 상압 가열건조법, 조회분은 건식 회화법, 조단백질은 Kjeldahl법으로 분석하 였다.

\section{Farinograph 측정}

케이크 반죽의 farinograph 측정은 $\mathrm{AACC}$ 법(43)에 따라 farinograph(Brabender-Farinograph, Duisburg, Germany)를 사용하여 측정하였다. Farinograph mixer bowl을 $30 \pm 0.2^{\circ} \mathrm{C}$ 로 유지시킨 다음 시료는 수분함량 $14.0 \%$ 기준으로 300 $\mathrm{g}$ 을 취하여 곡선의 중심점이 $500 \pm 10$ B.U.에 도달하도록 $30^{\circ} \mathrm{C}$ 의 물을 가하여 이때 수분 흡수율, 반죽도달시간, 반죽 형성시간, 안정도 및 연화도 등을 측정하였다.

Farinograph에서 믹서가 가동되어 물이 투입되고 난 후 그래프의 최고점이 500 B.U. 선에 도달하는데 필요로 하는 시간을 반죽도달시간, 최고점에 도달할 때까지의 시간을 반죽형성시간, 그래프의 상부가 500 B.U. 선을 최초로 횡단 하고 나서부터 그래프가 떨어지기 시작하여 그 상부가 다시 500 B.U. 선을 횡단하기까지의 시간을 안정도, 반죽의 혼합 20 분 후 그래프 폭의 중앙과 500 B.U. 선과의 거리를 연화도 로 표시하였다.

\section{Amylograph 측정}

케이크 반죽의 amylograph는 $\mathrm{AACC}$ 법(44)에 따라 amylograph(Brabender-Amylograph, Duisburg, Germany)를 사용하여 분석하였다. 시료 $65 \mathrm{~g}$ 에 증류수 $450 \mathrm{~mL}$ 를 첨가한

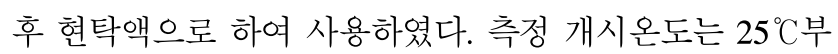
터 시작하여 호화개시온도, 최고점도온도 및 최고점도의 특성값을 측정하였다. 호화개시온도는 초기점도가 10 B.U. 에 도달하는 온도로 나타내었다.

\section{색 도}

케이크의 색도는 색차계(Js555, Color Techno System Co, Tokyo, Japan)를 이용하여 케이크는 중앙 부분을 원통형 $(3.5 \times 1.5 \mathrm{~cm})$ 으로 잘라 측정하였으며, L(lightness), a(redness) 그리고 $\mathrm{b}$ (yellowness)의 값을 측정하였다. 표준색판으로는 백판 $(\mathrm{L}=98.65, \mathrm{a}=0.07, \mathrm{~b}=-0.85)$ 을 사용하여 측정하였다.

\section{케이크의 외관 특성평가}

스펀지 케이크를 실온에서 1 시간 정도 냉각시킨 후 케이 크의 외관상 특성 평가로 부피지수(total volume index), 대 칭성지수(symmetry index) 및 균일성지수(uniformity index) 를 $\mathrm{AACC}(45)$ 방법에 따라 케이크의 중앙 부분을 절단한 후 측정하였다.

\section{반죽의 비중}

케이크 반죽을 완료한 후 비중(specific gravity)은 AACC 방법(46)에 따라 물의 무게에 대한 최종 케이크 반죽 무게의 비로 나타내었다.

$$
\text { 비중 }=\frac{\text { 같은 부피의 반죽 무게 }(\mathrm{g})}{\text { 같은 부피의 물 무게 }(\mathrm{g})}
$$

\section{케이크의 부피, 비용적 및 굽기 손실율}

버터스펀지 케이크의 무게는 구운 후 실온에서 1시간 동안 냉각시킨 후 측정하였고, 케이크의 부피는 종차 치환 법에 의해 네 개의 시료를 각각 네 번씩 측정한 값을 산술평 균으로 나타내었다. 비용적(specific loaf volume) 값은 반죽 $1 \mathrm{~g}$ 이 차지하는 부피이고, 굽기 손실율(baking loss rate(\%)) 수식은 다음과 같다.

Specific volume $(\mathrm{mL} / \mathrm{g})=\frac{\text { cake volume }(\mathrm{mL})}{\text { batter weight }(\mathrm{g})}$

Baking loss rate $(\%)=\frac{\text { batter weight-cake weight }(\mathrm{g})}{\text { batter weight }(\mathrm{g})} \times 100$

\section{텍스쳐}

스펀지 케이크를 실온에서 1시간 정도 냉각시킨 후 Rheometer(Compac-100 П, Sun Scientific Co., Ltd., Tokyo, Japan)를 사용하여 3회 반복 측정하여 통계 처리하였다. 시료는 케이크의 중심부를 $40 \times 40 \times 40 \mathrm{~mm}$ 의 크기로 잘라서 압착했을 때 얻어지는 force distance curve로부터 시료의 TPA(texture profile analysis)를 computer로 분석하여 경도 (hardness), 응집성(cohesiveness), 탄력성(springiness), 점착 성(gumminess), 깨짐성(brittleness)을 측정하였다. 이때 사 용된 탐침은 P20의 원통형을 장착하여 측정하였다.

\section{자료 분석}

실험 결과는 SPSS WIN program을 이용하여 평균값과 표준편차를 구하였고, 각 변수에 대한 유의성 검증은 One-way ANOVA를 이용하였으며, Duncan's multiple range test로 $p<0.05$ 수준에서 사후검증을 하였다. 


\section{결과 및 고찰}

\section{일반성분}

동결건조한 단호박의 일반성분은 수분이 $4.88 \%$ 정도였 으며, 단백질이 $4.40 \%$, 회분이 $4.018 \%$ 였다. 단호박 일반 성분에서 $\mathrm{Heo}$ 등(5)은 수분 $87.87 \%$, 단백질 $1.74 \%$, 회분 $0.91 \%$ 였으며, $\mathrm{Kim}$ 등(7)은 수분 $87.60 \%$, 단백질 $1.55 \%$, 회 분 $0.67 \%$ 로 차이가 있었다. 이로써 동결건조한 단호박의 분말이 수분이 건조됨으로써 제품을 제조했을 때 적은 양으 로도 영양성을 더 강화할 수 있어서 기호성이 높은 제품을 만들 수 있다고 사료된다.

\section{Farinograph 특성}

단호박 분말 첨가량에 따라서 farinogram 특성 값은 Table 2 와 같다. 대조구의 밀가루 흡수율은 $51.2 \%$ 였으며, 단호박 분말 3, 6\% 첨가구의 흡수율은 $52.0 \%$ 로 같았으며, $9 \%$ 첨가 구는 $52.7 \%, 12 \%$ 첨가구는 $52.3 \%$ 로 단호박 분말 첨가량이 증가할수록 약간 증가하는 경향을 나타내었다.

Table 2. Farinograph characteristics of wheat flour prepared by different levels of sweet pumpkin powder

\begin{tabular}{lccccc}
\hline \multirow{2}{*}{ Variables } & \multicolumn{5}{c}{ Addition levels of sweet pumpkin powder (\%) } \\
\cline { 2 - 6 } & 0 & 3 & 6 & 9 & 12 \\
\hline Water absorption (\%) & 51.2 & 52.0 & 52.0 & 52.7 & 52.3 \\
Elasticity (B.U.) & 140 & 140 & 140 & 140 & 140 \\
Development time (min) & 0.8 & 0.9 & 1.0 & 1.0 & 1.0 \\
Stability (min) & 5.0 & 2.6 & 3.2 & 3.0 & 3.3 \\
Weakness (B.U.) & 80 & 95 & 110 & 125 & 120 \\
Valorimeter value & 42 & 39 & 37 & 36 & 35 \\
\hline
\end{tabular}

탄력도는 대조구가 140 B.U.로 단호박 분말 첨가구와 모두 동일하게 나타났으며, 최고점에 도달하는 시간은 대 조구가 0.8 분으로 단호박 분말 $3 \%$ 첨가구가 0.9 분이었고, $6,9,12 \%$ 첨가구는 동일하게 1.0 분으로 조금 더 길게 나타났 다.

대조구 반죽의 안정도는 5.0 분이고, 약화도는 80 B.U.였 다. 단호박 분말의 첨가량이 증가에 따라 연화도가 커지다 가 $12 \%$ 때 120 으로 다소 감소하는 현상을 보였다. 강력도 (valorimeter value)는 밀가루의 품질을 평가할 수 있는 지표 로 이용되며, 반죽시간과 반죽에 대한 저항성을 기초로 하 여 유도되는 값으로 대조구가 42 이었고, 단호박 분말 첨가 량이 증가할수록 감소하는 것으로 나타났다. 이는 $\mathrm{Bae}$ 등 (2)의 단호박을 첨가한 빵의 품질 특성에서 단호박 분말 첨가량이 증가할수록 흡수율이 감소하는 결과와는 차이가 있었으며, 이는 빵에 사용하는 밀가루 단백질의 차이인 것 으로 사료된다. 또한 최고점에 도달하는 시간이 더 길게 나타난 결과는 일치하였다.

\section{Amylograph 특성}

단호박 분말 첨가량에 따른 amylogram 특성 값은 Table 3 과 같다. 대조구의 호화개시온도는 $61.5^{\circ} \mathrm{C}$ 였으며, 단호박 분말 첨가시 $64.0^{\circ} \mathrm{C}$ 로 대조구에 비해서 높게 나타났다. 최고 점도 온도는 대조구가 $97.0^{\circ} \mathrm{C}$ 였고, 단호박 분말 $3 \%$ 첨가시 대조구와 동일하게 나타났으며, $6,9,12 \%$ 첨가시 대조구보 다 낮게 나타났다. 최고점도는 대조구가 645 B.U.였고, 호박 분말 $3 \%$ 첨가 시 490 B.U., $6 \%$ 첨가 시 450 B.U., $9 \%$ 첨가 시 410 B.U., $12 \%$ 첨가 시 400 B.U.로 감소하는 경향을 보였다. 최고 점도는 효소의 활성 이외에 점도의 팽윤정도 에 크게 영향을 받는다. 이와 같은 결과는 $\mathrm{Bae}$ 등(2)의 단호 박 분말 첨가량이 증가할수록 호화개시온도는 낮아진 결과 와는 차이가 있었다. 최고점도는 단호박 분말 첨가량이 증 가할수록 대조구보다 낮아진 $\mathrm{Bae}$ 등(2)의 결과와 일치하였 으며, 이는 효소의 활성 이외에 전분의 팽윤 정도에 영향을 크게 받기 때문이며(50), 단호박 분말 첨가에 따른 전분의 희석 효과에 관련된 것으로 사료된다(2)

Table 3. Amylograph characteristics of wheat flour prepared by different levels of sweet pumpkin powder

\begin{tabular}{ccccc}
\hline $\begin{array}{c}\text { Addition levels of sweet pumpkin } \\
\text { powder (\%) }\end{array}$ & ST $\left({ }^{\circ} \mathrm{C}\right)^{1)}$ & GT $\left({ }^{\circ} \mathrm{C}\right)$ & MT $\left({ }^{\circ} \mathrm{C}\right)$ & $\begin{array}{c}\text { MV } \\
(\text { B.U. })\end{array}$ \\
\hline 0 & 25 & 61.5 & 97.0 & 645 \\
3 & 25 & 64.0 & 97.0 & 490 \\
6 & 25 & 64.0 & 95.0 & 450 \\
9 & 25 & 64.0 & 94.0 & 410 \\
12 & 25 & 64.5 & 91.5 & 400 \\
\hline
\end{tabular}

${ }^{11} \mathrm{ST}$, starting temperature; GT, gelatinization temperature; MT, temperature at maximum viscosity; MV, maximum viscosity.

색 도

단호박 분말 첨가량을 달리하여 제조한 버터스펀지 케이 크의 crust(외부)와 crumb(내부)의 색도를 측정한 결과는 Table 4와 같다. 버터 스펀지케이크의 명도를 나타내는 L 값은 crust에서 호박분말 $3 \%$ 첨가구가 대조구보다 높았고, $6,9,12 \%$ 첨가구는 감소하였으며 $(\mathrm{p}<0.01), \mathrm{crumb}$ 도 대조구 보다 낮게 나타나 어두운 색을 나타내었다.

적색도 a 값은 crust에서 대조구가 14.98이였으며, 단호박 분말 $3 \%$ 첨가구는 15.36 으로 다소 높게 나왔으나, $6 \%, 9 \%$, $12 \%$ 첨가구는 대조구보다 낮게 나타났고 $(\mathrm{p}<0.05), \mathrm{crumb}$ 도 대조구보다 낮게 나타났다( $\mathrm{p}<0.05)$. 황색도 $\mathrm{b}$ 값은 crust의 대조구가 28.39로, 단호박 분말 $3 \%$ 첨가구가 30.91로 높아 졌으며, 그 외 첨가구는 대조구보다 낮아졌으나 $(\mathrm{p}<0.001)$, $\mathrm{crumb}$ 에서는 대조구보다 단호박 분말 첨가량의 증가에 따 라 높게 나타났다(p<0.001). 이는 Lee와 $\operatorname{Han}(1), \mathrm{Bae}$ 등(2), Woo 등(39)의 단호박 분말의 첨가량이 증가할수록 L 값은 증가한다고 하였으며, $\mathrm{a}$ 값은 Lee와 $\mathrm{Han}(1), \mathrm{Bae}$ 등(2)은 
Table 4. Color values of sponge cakes containing different levels of sweet pumpkin powder

(Mean \pm SD)

\begin{tabular}{|c|c|c|c|c|c|c|c|}
\hline \multirow{2}{*}{\multicolumn{2}{|c|}{ Color Values ${ }^{1)}$}} & \multicolumn{5}{|c|}{ Addition levels of sweet pumpkin powder(\%) } & \multirow{2}{*}{ F-value } \\
\hline & & 0 & 3 & 6 & 9 & 12 & \\
\hline \multirow{3}{*}{ Crust } & $\mathrm{L}$ & $54.78 \pm 4.20^{\mathrm{c} 2)}$ & $56.71 \pm 1.56^{\mathrm{cd}}$ & $52.23 \pm 1.19^{\mathrm{bc}}$ & $1.89 \pm 0.60^{b}$ & $45.61 \pm 1.54^{\mathrm{a}}$ & $12.08^{\star * 3)}$ \\
\hline & a & $14.98 \pm 0.13^{\mathrm{bc}}$ & $15.36 \pm 0.55^{\mathrm{c}}$ & $14.66 \pm 0.49^{\mathrm{ab}}$ & $14.48 \pm 0.10^{\mathrm{ab}}$ & $14.19 \pm 0.15^{\mathrm{a}}$ & $5.62^{*}$ \\
\hline & $b$ & $28.39 \pm 1.92^{\mathrm{b}}$ & $30.91 \pm 0.86^{\mathrm{c}}$ & $26.14 \pm 0.81^{\mathrm{a}}$ & $28.42 \pm 0.50^{\mathrm{b}}$ & $24.09 \pm 1.27^{\mathrm{a}}$ & $14.41^{* * *}$ \\
\hline \multirow{3}{*}{ Crumb } & $\mathrm{L}$ & $82.13 \pm 0.48$ & $81.20 \pm 0.90$ & $79.88 \pm 0.62$ & $79.22 \pm 15.74$ & $78.42 \pm 0.22$ & 1.63 \\
\hline & a & $-0.80 \pm 0.15^{\mathrm{a}}$ & $-1.39 \pm 0.38^{b}$ & $-1.41 \pm 0.06^{b}$ & $-1.12 \pm 0.22^{\mathrm{ab}}$ & $-0.72 \pm 0.18^{\mathrm{a}}$ & $6.16^{*}$ \\
\hline & $\mathrm{b}$ & $33.93 \pm 1.10^{\mathrm{a}}$ & $42.75 \pm 0.91^{b}$ & $48.97 \pm 0.08^{c}$ & $55.03 \pm 2.57^{\mathrm{d}}$ & $58.81 \pm 0.74^{d}$ & $158.72^{* * \star}$ \\
\hline
\end{tabular}

${ }^{1)}$ L, lightness (white; +100-black, 0); a, redness (red; +100-green; -80); b, yellowness (yellow; +70-blue; -70).

${ }^{2)}$ Means followed by the same letter in column are not significantly different $(\mathrm{p}<0.05)$.

$\left.{ }^{3}\right)^{*}<0.05, \stackrel{* *}{\mathrm{p}}<0.01,{ }^{* * *} \mathrm{p}<0.001$.

낮아지고 Woo 등(39)은 높아진다고 하여 차이가 있었고, $\mathrm{b}$ 값은 높아진다는 결과와 유사한 경향이었다.

이와 같은 결과는 굽기 과정에서 일어나는 환원당과 아 미노 화합물의 메일라드 반응 및 당의 캐러멜화 반응에 의한 갈색화가 단호박의 첨가량이 증가할수록 당 함량도 증가하여 구웠을 때 생긴 갈변현상이 진전 된 것으로 생각 되며, 단호박 분말 첨가량이 색도에 영향을 주는 것으로 나타났다.

\section{비 중}

단호박 분말 첨가량을 달리하여 제조한 반죽의 비중을 측정한 결과는 Table 5 와 같다. 케이크 반죽의 비중은 반죽 내 기포형성 정도를 나타내고, 적당한 기포형성은 바람직 한 제품의 케이크 제조에 매우 중요하며(47), 반죽의 비중이 낮다는 것은 반죽에 많은 공기가 함유되어 있음을 의미한다.

일반적으로 스펀지 케이크의 비중값은 $0.45-0.50$ 의 범위 안에 나타난다. 대조구의 경우 비중이 0.46 이었고 단호박

Table 5. Specific gravity of butter sponge cakes containing different levels of sweet pumpkin powder

\begin{tabular}{cccccc}
\hline \multirow{2}{*}{ Variables } & \multicolumn{5}{c}{ Addition levels of sweet pumpkin powder (\%) } \\
\cline { 2 - 6 } & 0 & 3 & 6 & 9 & 12 \\
\hline Specific gravity & $0.46 \pm 0.01$ & $0.47 \pm 0.01$ & $0.47 \pm 0.02$ & $0.50 \pm 0.01$ & $0.52 \pm 0.02$ \\
\hline
\end{tabular}

분말 $3,6 \%$ 첨가구는 $0.47,9 \%$ 첨가구는 $0.50,12 \%$ 첨가구는 0.52 로 나타났다. 이는 $\operatorname{Park}(38)$ 의 단호박 분말 첨가량이 증가함에 따라 비중이 높아지는 경향과 유사하며, 밀가루 의 일부가 식이성 섬유소 함량이 높은 부재료로 대체되어 제조된 대부분의 기능성 케이크류의 결과와 일치하였다 (48).

\section{케이크의 부피, 무게, 비용적 및 굽기 손실율}

단호박 분말을 첨가하여 제조한 버터스펀지 케이크의 부피, 무게, 비용적 및 굽기 손실율을 측정한 결과는 Table 6와 같다. 케이크의 부피는 대조구가 $1,977.5 \mathrm{~mL}$ 였고, 단호 박 분말 $3 \%$ 첨가구는 $1,967.5 \mathrm{~mL}, 6 \%$ 첨가구는 $1,965 \mathrm{~mL}$, $9 \%$ 첨가구는 $1,922.5 \mathrm{~mL}, 12 \%$ 첨가구는 $1,897.5 \mathrm{~mL}$ 로 부피 가 감소하였다. 이는 Lee 등(40)과 Park 등(49)의 연구 결과 에서도 부재료의 양이 증가함에 따라 부피가 감소하는 결과 와 비슷한 경향을 보였다.

버터스펀지 케이크의 비용적은 대조구가 4.39 였으며, 단 호박 분말 $3 \%, 6 \%$ 첨가구가 4.37 로 같게 나타났고, $9 \%$ 첨가구는 $4.27,12 \%$ 첨가구는 4.22 로 감소하는 경향으로 나타났다. 대조구의 굽기 손실율은 $6.28 \%$ 였으며, 단호박 분말을 첨가할수록 $5.89 \%$ 로 감소하였고, $12 \%$ 첨가구는 $6.62 \%$ 로 약간 증가하는 경향이었는데 이는 평균 오차에서 비롯된 차이이며 오차 범위 내에서는 굽기 손실율이 감소

Table 6. Baking loss rate and specific volume white cake prepared by different levels of sweet pumpkin powder

\begin{tabular}{ccccccc}
\hline \multirow{2}{*}{ Variables } & \multicolumn{5}{c}{ Addition levels of sweet pumpkin powder (\%) } & F-value \\
\cline { 2 - 6 } & 0 & 3 & 6 & 9 & 12 & 2.07 \\
Cake volum $(\mathrm{mL})$ & $1,977.50 \pm 45.00$ & $1,967.50 \pm 41.93$ & $1,965.00 \pm 56.86$ & $1,922.50 \pm 61.85$ & $1,897.50 \pm 23.63$ \\
Cake weight $(\mathrm{g})$ & $421.75 \pm 2.06$ & $423.75 \pm 2.06$ & $423.00 \pm 2.16$ & $423.50 \pm 0.58$ & $420.23 \pm 2.03$ & 2.42 \\
Specific volume $(\mathrm{mL} / \mathrm{g})$ & 4.39 & 4.37 & 4.37 & 4.27 & 4.22 & 6.62 \\
Baking loss rate $(\%)$ & 6.28 & 5.83 & 6.00 & 5.89 & 6 \\
\hline
\end{tabular}


하는 것으로 나타났다. 이는 Bae 등(2)의 연구 결과와 유사 하며, Kim 등(50)의 연구에서 굽기 손실은 발효 산물 중에서 휘발성 물질이 휘발하면서 수분이 증발한 것으로 같은 굽기 조건에서 손실율이 증가할수록 호화가 양호하고 껍질의 착색도 좋다고 보고되고 있다.

\section{케이크의 단면과 외관 관찰}

단호박 분말을 첨가하여 제조한 버터스펀지 케이크의 외관상 특성평가로 부피 지수(volume index), 대칭성 지수 (symmetry index) 및 균일성 지수(uniformity index)를 측정 한 결과는 Table 7과 같으며, 외관 및 단면 사진은 Fig. 2 와 같다. 케이크의 최종 부피는 반죽 시 형성된 기포가 굽기 과정까지 안전하게 유지되어야 유리한 것으로 알려져 있 다. 부피 지수는 대조구가 18.48 이었으며 단호박 분말 $3 \%$
첨가구는 $17.63,6,9,12 \%$ 첨가구는 각각 $17.98,17.23,17.53$ 으로 단호박 분말 첨가량이 증가할수록 감소하였다 $(p<0.01)$. 이는 종자치환법으로 측정한 케이크의 부피와 유 사한 결과를 나타내었다.

케이크의 대칭성, 균형성을 나타내는 대칭성 지수는 대 조구가 0.95로 가장 좋았으며 단호박 첨가구의 경우는 대조 구보다 대칭성이 낮은 경향을 보였다(p<0.05). 케이크가 좌 우로 어느 정도 치우침이 있는지를 알아보는 균일성 지수는 대조구가 -0.55 였으며, 단호박 분말 $3 \%$ 첨가구는 $-0.15,6 \%$ 첨가구는 $-0.33,9 \%$ 첨가구는 $-0.28,12 \%$ 첨가구는 -0.40 으 로 감소하는 경향을 나타내었다( $\mathrm{p}<0.05)$.

\section{텍스쳐}

단호박 분말 첨가량을 달리하여 제조한 버터스펀지 케이

Table 7. Appearance characteristics of sponge cakes containing different levels of sweet pumpkin powder

(Mean \pm SD)

\begin{tabular}{lcccccc}
\hline \multirow{2}{*}{ Variables } & \multicolumn{5}{c}{ Addition levels of sweet pumpkin powder $(\%)$} & F-value \\
\cline { 2 - 6 } & 0 & 3 & 6 & 9 & 12 & $7.75^{* * 2)}$ \\
Volume index & $18.48 \pm 0.25^{\mathrm{cl})}$ & $17.63 \pm 0.25^{\mathrm{ab}}$ & $17.98 \pm 0.21^{\mathrm{b}}$ & $17.23 \pm 0.13^{\mathrm{a}}$ & $17.53 \pm 0.43^{\mathrm{a}}$ & \\
Symmetry index & $0.95 \pm 0.26^{\mathrm{b}}$ & $0.61 \pm 0.22^{\mathrm{a}}$ & $0.63 \pm 0.21^{\mathrm{ab}}$ & $0.65 \pm 0.29^{\mathrm{ab}}$ & $0.70 \pm 0.36^{\mathrm{b}}$ & $3.72^{*}$ \\
Uniformity index & $-0.55 \pm 0.17^{\mathrm{c}}$ & $-0.15 \pm 0.06^{\mathrm{a}}$ & $-0.32 \pm 0.15^{\mathrm{abc}}$ & $-0.28 \pm 0.17^{\mathrm{ab}}$ & $-0.40 \pm 0.14^{\mathrm{bc}}$ & $4.20^{*}$ \\
\hline
\end{tabular}

${ }^{1)}$ Means followed by the same letter in column are not significantly different $(\mathrm{p}<0.05)$.

${ }^{2)^{*}} \mathrm{p}<0.05,{ }^{* *} \mathrm{p}<0.01$.
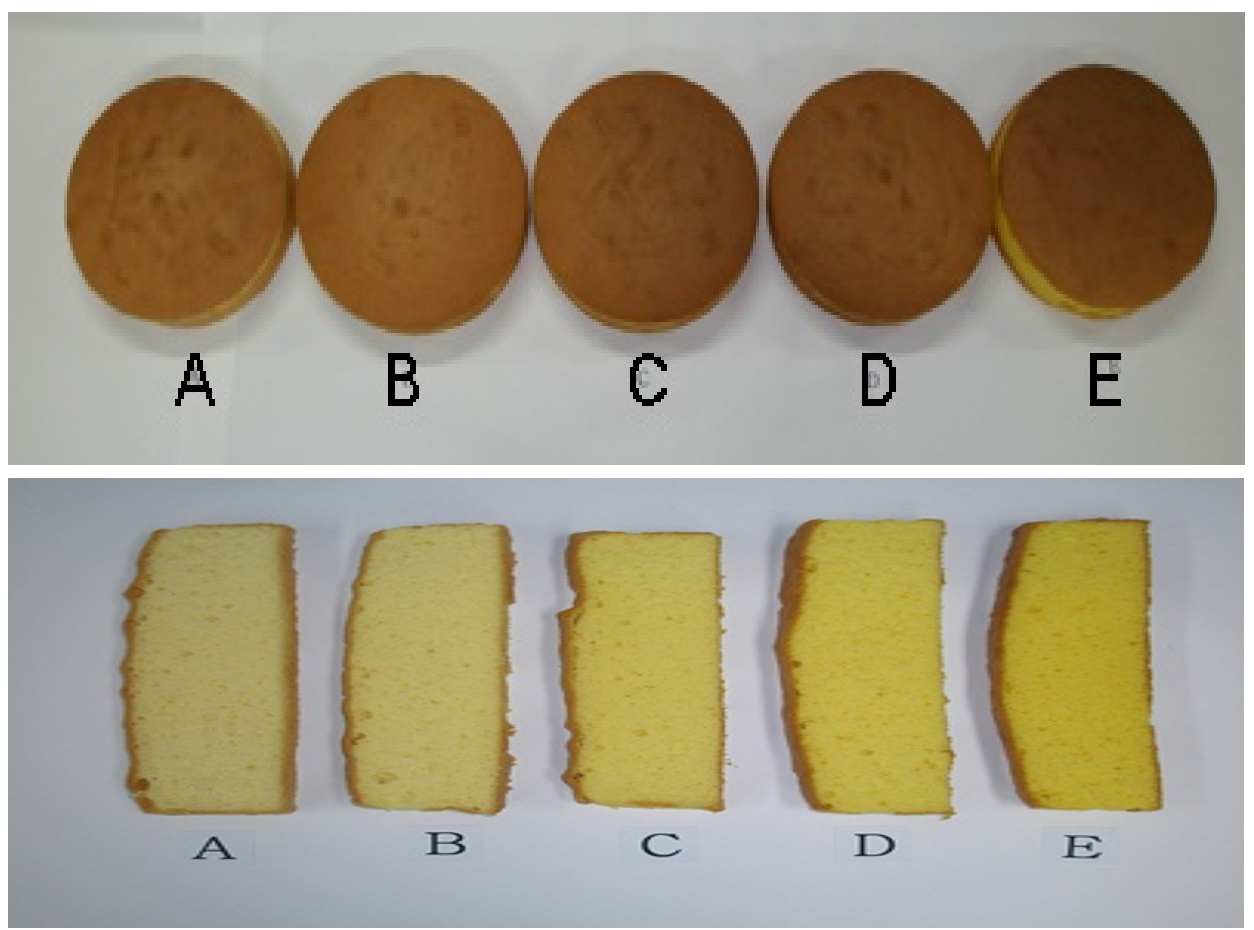

Fig. 2. Cut loaves and appearance of the white cake prepared by different levels of sweet pumpkin powder.

A, addition levels of sweet pumpkin powder $0 \%$; B, addition levels of sweet pumpkin powder 3\%; C, addition levels of sweet pumpkin powder 6\%; D, addition levels of sweet pumpkin powder $9 \%$; $\mathrm{E}$, addition levels of sweet pumpkin powder $12 \%$. 
Table 8. Textural characteristics of butter sponge cakes containing different levels of sweet pumpkin powder

(Mean \pm SD)

\begin{tabular}{lcccccc}
\hline \multirow{2}{*}{ Variables } & \multicolumn{5}{c}{ Addition levels of sweet pumpkin powder (\%) } & \multirow{2}{*}{ F-value } \\
\cline { 2 - 6 } & 0 & 3 & 6 & 9 & 12 & $4.52^{* 2)}$ \\
\hline Hardness & $114.58 \pm 30.81^{\text {al }}$ & $124.13 \pm 18.43^{\mathrm{b}}$ & $118.52 \pm 13.38^{\mathrm{b}}$ & $122.06 \pm 15.21^{\mathrm{b}}$ & $125.49 \pm 10.96^{\mathrm{b}}$ & \\
Springness & $80.97 \pm 1.35$ & $84.71 \pm 5.42$ & $89.19 \pm 6.16$ & $88.02 \pm 1.61$ & $88.47 \pm 3.24$ & 2.50 \\
Cohesiveness & $80.40 \pm 3.48$ & $87.36 \pm 7.72$ & $96.09 \pm 12.55$ & $95.42 \pm 4.57$ & $92.69 \pm 6.21$ & 2.45 \\
Gumminess & $83.13 \pm 10.75$ & $86.38 \pm 11.41$ & $86.34 \pm 10.05$ & $87.12 \pm 6.27$ & $87.76 \pm 4.22$ & 1.60 \\
Brittleness & $90.04 \pm 11.98^{\mathrm{b}}$ & $80.86 \pm 4.76^{\mathrm{b}}$ & $80.62 \pm 7.10^{\mathrm{b}}$ & $79.37 \pm 4.99^{\mathrm{a}}$ & $77.64 \pm 4.57^{\mathrm{a}}$ & $6.14^{* *}$ \\
\hline
\end{tabular}

${ }^{1)}$ Means followed by the same letter in column are not significantly different $(\mathrm{p}<0.05)$.

2) $\mathrm{p}<0.05, \quad{ }^{* *} \mathrm{p}<0.01$.

크의 텍스쳐 특성으로 경도, 탄력성, 응집성, 점착성 및 깨짐 성 등을 측정하였으며 그 결과는 Table 8 과 같다. 경도는 대조구가 114.58로 단호박 분말을 첨가했을 때가 다소 높게 나타났으며(p<0.05), Park(38), Woo 등(39)과 Moon 등(51) 의 첨가량이 증가할수록 경도가 증가한다는 결과와 비슷하 였다. Park(38)은 기포의 얇은 막 형성과 기포의 팽창을 방해하여 케이크 내부 조직을 단단하게 만들기 때문이라고 하였다.

탄력성과 응집성은 대조구가 각각 $80.97,80.40$ 으로 단호 박 분말을 첨가했을 때 다소 높아졌으나 유의적인 차이는 없었고, 검성은 대조구가 83.13이였으며 단호박 분말을 첨 가했을 때 다소 높아졌으나 유의적인 차이는 없었다. 이는 $\operatorname{Park}(38)$ 과 Woo 등(39)의 연구 결과와 유사하였다. 깨짐성 은 대조구가 90.04 였고, 단호박 분말을 첨가할수록 낮아졌 으며, $9 \%, 12 \%$ 첨가구에서 차이가 있었다 $(\mathrm{p}<0.01)$.

\section{요 약}

본 연구는 영양성과 기능성 뿐만 아니라 소비자의 기호 성이 높은 식품을 개발하고, 베이커리 제품의 부가가치를 높이고자 단호박을 동결 건조하여 버터스펀지 케이크에 단호박 분말 첨가량을 $0,3,6,9,12 \%$ 로 달리하여, 반죽의 farinograph, amylograph, 비중의 물리적 특성과 품질 특성 인 색도, 부피, 무게, 비용적 및 굽기 손실율, 텍스쳐 등에 대한 연구를 수행하였다. 반죽의 farinogram 특성은 단호박 분말 첨가량이 증가할수록 흡수율은 약간 증가하였고, 최 고점에 도달하는 시간은 조금 더 길게 나타났으며, 연화도 는 첨가량에 따라 증가하다가 $12 \%$ 에서 다소 감소하였다. Amylogram 특성에서 단호박 분말 첨가시 호화개시온도는 대조구에 비해서 높게 나타났으며, 최고점도는 낮게 나타 났다. 비중은 단호박 분말 첨가량이 증가함에 따라 높아졌 다. 색도에서 crust의 $\mathrm{L}$ 값 $(\mathrm{p}<0.01), \mathrm{a}$ 값 $(\mathrm{p}<0.05), \mathrm{b}$ 값 $(\mathrm{p}<0.001)$ 은 대조구보다 낮아졌으며, crumb의 L 값, $\mathrm{a}$ 값 $(p<0.05)$ 은 대조구보다 낮아졌으나 $b$ 값 $(p<0.001)$ 은 높아졌
다. 부피와 비용적, 굽기 손실율은 대조구보다 감소하는 것으로 나타났으며, 부피 지수는 대조구보다 단호박 분말 첨가량이 증가할수록 감소하였고 $(\mathrm{p}<0.01)$, 대칭성 지수는 대조구가 가장 좋았으며 단호박 첨가구는 대조구보다 낮은 경향을 보였다 $(\mathrm{p}<0.05)$. 텍스쳐 특성에서는 경도는 단호박 분말을 첨가했을 때가 다소 높게 나타났고 $(\mathrm{p}<0.05)$, 깨짐성 은 단호박 분말을 첨가할수록 낮아졌으며 $9,12 \%$ 첨가구에 서 차이가 있었다 $(\mathrm{p}<0.01)$. 이와 같은 결과에서 단호박 분말 첨가량이 9-12\%일 때 가장 좋은 최적 조건을 나타내어서 소비자의 선호도가 높은 단호박 버터스펀지 케이크를 제조 하여 부가가치를 높이고 상품성을 증대시켜 베이커리 제품 의 다양화와 소비자의 만족도를 증대할 수 있다고 사료된 다.

\section{References}

1. Lee GS, Han GP (2013) Quality characteristics of bread supplemented with sweet pumpkin. Korean J Food Cult, 28, 386-391

2. Bae JH, Woo HS, Jung IC (2006) Rheological properties of dough and quality characteristics of bread added with pumpkin powder. Korean J Food Culture, 21, 311-318

3. Wils RBH, Lim JSK, Greenfield H (1987) Composition of Australian, 39 vegetable fruits. Food Technol Australia, 39, 488-498

4. Lee KS, Hwang CS (1990) A study on the actual utilization Korean traditional remedies-about foods used on geriatric disease. J Korean Diet Cult, 5, 331-347

5. Heo SJ, Kim JH, Kim JK, Moon KD (1998) The comparison of food constituents in pumpkin and sweet pumpkin. J Korean Diet Cult, 13, 91-96

6. Heo SJ, Kim JH, Kim JG, Moon KD (1998) Processing puree from pumpkin and sweet-pumpkin. Korean $\mathbf{J}$ Postharvest Sci Technol, 5, 172-176 
7. Kim SR, Ha TY, Song HN, Kim YS, Park YK (2005) Comparison of nutritional composition and antioxidative activity for kabocha squash and pumpkin. Korean J Food Sci Technol, 37, 171-177

8. Park YK, Cha HS, Park MW, Kang YH, Seog HM (1997) Chemical components in different parts of sweet pumpkin. J Korean Soc Food Sci Nutr, 26, 639-646

9. Jang SM, Park NY, Lee JB, Ahn H (2001) The comparison of food constituent in different parts of sweet pumpkin. J Korean Soc Food Sci Nutr, 30, 1038-1040

10. Lee JS, Park YJ, Hwang TY, Kim IH, Kim SI, Moon KD (2003) Quality characteristics of minimally processed sweet-pumpkin during storage. Korean J Food Preserv, $10,6-10$

11. Hong YS, Kim KS (2017) Effect of cooking methods on elemental composition of pumpkin (Cucurbitaceae spp.). J Korean Soc Food Sci Nutr, 46, 1195-1204

12. Kim HE, Hwang MR, Park DK, Heu YC, Lee HJ, Kang NJ (2014) Changes in the activity of antioxidant enzymes depending on ripening levels in Cucurbita spp.. J Agric Life Sci, 48, 59-66

13. Youn SJ, Rhee JK, Yoo SH, Chung MS, Lee HJ (2016) Total phenolics contents, total flavonoids contents and antioxidant capacities of commercially available Korean domestic and foreign intermediate food materials. Microbiol Biotechnol Lett, 44, 278-294

14. Park DS, Hyun JY, Kown HS, Jeong CS (2016) Effect of $\mathrm{NaOCl}$ and citric acid pre-treatment for long-term storage of winter squash 'Bochang'. J Agric Life Environ Sci, 28, 1-9

15. Hyun IH, Heo NY, Ryu KY, Kim JT, Chang SY (2004) Identification of Verticillium tenerum isolated from potato and pumpkin in Korea. Korean J Mycol, 32, 45-49

16. Hong JH, Lee WY (2004) Quality characteristics of osmotic dehydrated sweet pumpkin by different drying methods. J Korean Soc Food Sci Nutr, 33, 1573-1579

17. Na KM, Hong JH, Cha WS, Park Jh, Oh SL, Cho YJ, Lee WY (2004) Optimization of osmotic dehydration process for manufacturing a dried sweet pumpkin. $\mathrm{J}$ Korean Soc Food Sci Nutr, 33, 433-438

18. Oh BY, Jo GS, Lee YS, Kang JH, Jang MH, Hwanbo IS (2015) Quality change of mini sweet pumpkins (suppress cultivation, fall planting) during storage at different conditions. Korean J Food Preserv, 22, 779-787

19. Shin DS, Yoo SM, Hwang Y (2012) Effect of sugar infusions and pretreatment conditions on quality characteristics of dried sweet pumpkin. Korean J Food
Cookery Sci, 28, 857-863

20. Park JH, Choi JE, Lee JH (2015) Selected physicochemical and consumer preference characteristics of noodles incorporated with sweet pumpkin powder. J Korean Soc Food Nutr, 44, 291-295

21. Chang KH, Cho KH, Kang MK (2012) Optimization of the preparation conditions and quality characteristics of sweet pumpkin-Doenjang sauce. Korean J Food Preserv, $19,492-500$

22. Jung HA, Kim AN, Ahn EM, Kim YJ, Park SH, Lee JE, Lee SM (2011) Quality characteristics of curd yogurt with sweet pumpkin. Korean J Food Preserv, 18, 714-720

23. Park HK, Yim SK, Sohn KH, Kim HJ (2001) Preparation of semi-solid foods instant using sweet pumpkin. J Korean Soc Food Nutr, 30, 1108-1114

24. An YH, Lee IB, Kim HS (2011) Quality characteristics of Sikhye with varied levels of sweet pumpkin during storage. Korean J Food Cookery Sci, 27, 803-814

25. Kim MH, Lee WM, Lee HJ, Park DK, Lee MH, Youn SJ (2012) Quality characteristics of the flesh and juice for different varieties of sweet pumpkin. Korean J Food Preserv, 19, 672-680

26. Han CW, Park WJ, Seung SK (2008) Optimization of the preparation conditions and quality characteristics of sweet pumpkin stock. Korean J Food Preserv, 15, 832-839

27. Kim DS (2012) The quality characteristics of powder pumpkin soup by different varieties of pumpkins and addition ratios. Korean J Culinary Res, 18, 65-76

28. Kim JM, Rho YH, Yoo YJ (2004) Quality properties of cream soup added with Chungdong pumpkin and sweet pumpkin. J Korean Soc Food Nutr, 33, 1028-1033

29. Choi EH, Chung JH (2018) Characteristics of sweet pumpkin Yanggaeng with stevia leaf powder as partial replacer of sucrose. Culinary Sci Hospitality Res, 24, 83-92

30. Lee JH, Lee MK (2013) Quality characteristics of Jelly incorporated with sweet pumpkin powder. J Korean Soc Food Nutr, 42, 139-142

31. Yun SJ (1999) Sensory and quality characteristics of pumpkin rice cake prepared with different amounts of pumpkin. Korean J Soc Food Sci, 15, 586-590

32. Jeong SH, Ahn HK, Lee KI (2013) The storage and quality characteristics of Duteoptteok added with sweet pumpkin. Foodservice Ind J, 9, 21-33

33. Jeong KY, Kim MY, Chun SS (2008) Quality characteristics of Sulgidduk with concentrated sweet pumpkin powder. Korean J Food Cookery Sci, 24, 
849-855

34. Lee CH, Chun SS, Kim MY (2008) Quality characteristics of hard roll bread with concentrated sweet pumpkin powder. J Korean Soc Food Sci Nutr, 37, 914-920

35. Park ID (2012) Effect of sweet pumpkin powder on quality characteristics of cookies. Korean J Food Culture, 27, 89-94

36. Lee SM, Ko YJ, Jung HA, Paik JE, Joo NM (2005) Optimization of iced cookie with the addition of dried sweet pumpkin powder. Korean J Food Cult, 20, 516-524

37. Lee SM, Joo NM (2007) The optimization of muffin with the addition dried sweet pumpkin powder. J Korean Diet Assoc, 13, 368-378

38. Park ID (2008) Effects of Cucurbita maxima duchesne puree on quality characteristics of pound and sponge cakes. Korean J Food Cult, 23, 748-754

39. Woo IA, Kim YS, Choi HS, Song TH, Lee SK (2006) Quality characteristics of sponge cake with added dried sweet pumpkin powders. Korean J Food Nutr, 19, 254-260

40. Lee MH, Lee SY, Lee SA, Choi YS (2010) Physicochemical characteristics of rice flour sponge cake containing various levels of pumpkin flour. Korean J Food Nutr, 23, 162-170

41. Korea Health Industry Development Institute (1998) National health and nutrition survey, Ministry of Health and welfare, Seoul, Korea, p 141

42. AOAC (1995) Official Methods of Analysis. $16^{\text {th }}$ ed, Association of Official Analytical Chemists, Washington DC, USA, p 36
43. AACC (1985) Approved Method of the AACC. $8^{\text {th }}$ ed, American Association of Cereal Chemists, St Paul, MN, USA, p 54-21

44. AACC (1985) Approved Method of the AACC. $8^{\text {th }}$ ed, American Association of Cereal Chemists, St Paul, MN, USA, p 22-10

45. AACC (1985) Approved Method of the AACC. $8^{\text {th }}$ ed, American Asociation of Cereal Chemists, St Paul, MN, USA, p 10-91

46. AACC (1983) Approved Method of the AACC. $8^{\text {th }}$ ed, American Association of Cereal Chemists, St Paul, MN, USA, p 10-10A

47. Pyler EJ (1979) Physical and Chemical Test Methods Baking Science and Technology Vol П. Sosland Pub Co, Manhattan, KS, USA, p 891-895

48. Oh SC, Nam HY, Cho JS (2002) Quality properties and sensory characteristics of sponge cake as affected by additions of Dioscorea japonica flour. Korean J Soc Food Cookery Sci, 18, 185-192

49. Park YR, Han IJ, Kim MY, Choi SH, Shin DW, Chun SS (2008) Quality characteristics of sponge cake prepared with red ginseng marc powder. Korean J Food Cookery Sci, 24, 236-242

50. Kim SK, Cheigh HS, Kwon TW, D’Appolonia BL, Marston PE (1978) Rheological and baking studies of composite flour wheat and naked barley. Korean J Food Sci Technol, 10, 247-251

51. Moon HK, Han JH, Kim JH, Kim JK, Kang WW, Kim GY (2004) Quality characteristics of the breads added with freeze dried old pumpkin powders. Korean J Soc Food Cookery Sci, 20, 126-132 